\title{
THE DIFFERENCE ANALYSIS OF ABNORMAL RETURN AND TRADE VOLUME ACTIVITY BEFORE AND AFTER RAMADHAN EFFECTS ON FOOD AND BEVERAGES COMPANIES LISTED IN INDONESIAN SHARIA STOCK INDEX (ISSI)
}

\author{
Titin Hartini', Amri Amir²), Junaidi ${ }^{3)}$, Tona Aurora Lubis ${ }^{4)}$ \\ ${ }^{1)}$ Faculty of Economics and Business Islamic, UIN Raden Fatah Palembang, Palembang Indonesia \\ 2,3,4) Faculty of Economics and Business, Universitas Jambi, Jambi Indonesia \\ Corresponding email: titinhartini_uin@radenfatah.ac.id
}

\begin{abstract}
This study aims to determine the difference between abnormal return and trade volume activity before and after Effects on Food And Beverages Companies Listed in Indonesian Sharia Stock Index (ISSI) in 2012 until 2017. In this study, samples were taken as many as 7 companies in the food and beverages sector. Researchers use quantitative research methods. The sampling technique used is purposive sampling. The type of data used is secondary data. Data analysis techniques are use parametric paired sample t-test and non parametric wilcoxon sign rank test using IBM SPSS 23 program.The results showed that there were significant differences of abnormal return between the month of sha'ban and syawal with significance value $0.003<0$.05. However there is a significant difference in trade volume activity between the month of sha'ban and the month of syawal with a significance value of $0.003<0.05$. it can be concluded that Ramadhan has information on the market that causes abnormal return and changes in trade volume activity.
\end{abstract}

\section{Keywords: Abnormal Return, Trade Volume Activity, Ramadhan Effect, Market Anomaly}

\section{Introduction}

Capital markets are markets that bring together parties seeking and needing funds. In the capital market there are various types of companies with the performance of each company that can be chosen by investors to invest in various types of securities. The Islamic capital market in Indonesia began in 1997 with the launch of the Islamic mutual fund, the Jakarta Islamic Index (JII) in 2000. Then in 2011 the Indonesian Sharia Stock Index (ISSI) was also launched. Capital markets are inseparable from the influence of the environment and society, especially in economics and politics. Although it is not directly related to the situation in the capital market, non-economic influences cannot be separated from capital market activities.

According to Fama (1970), the market is said to be efficient if the price formed in the market is a picture or reaction of existing information. In another case, a lot of research supports the efficient market concept. And on the other hand there is research that states that deviations from the efficient market hypothesis are market anomalies that can affect stock prices. These deviations are among others The Day of Week Effect, Monday Effect, Week Four Effect, Rogalsky Effect, January Effect, March Effect, Ramadhan Effect. One of signal of anomaly that occurs in Muslim-majority countries, the anomaly of Ramadhan Effect. Ramadhan is the ninth month of the Islamic calendar. During the month of Ramadhan the majority of Muslims will start fasting and attach importance to religious matters. During the month of Ramadhan, public consumption will increase, especially at the beginning of the Shawwal and to celebrate Eid al-Fitr. This has resulted in increased prices for basic needs of the community due to the high level of public consumption.

According to Arief (2016), in the Republika daily, seen from the Aprindo data, during the fasting month there was an increase in community consumption of around $20 \%$ to $30 \%$ compared to other months. There are three factors that cause the increase in public consumption. First, the amount of food and drinks served when breaking the fast. Second, the attraction of Eid during the holy month of Ramadhan so that the community has prepared all kinds of needs during the month of Ramadhan. Third, the holy month of Ramadhan is a spirit month for Muslims to share with others and build caring. According to David Sutyanto (2017), revealed that stocks that are always hunted towards the month of Ramadhan are usually the retail and consumer goods sectors. According to him, with increasing public consumption up to 2 times the potential to affect the performance of shares of the sector.

\section{Literature Review}

Return of stock is the income was received by investors as the output of investment in a particular company. According to Jogiyanto (2008), return is one picture of a stock situation that is the most valid, if the return received by investors is high, then the stock is in good condition, and vice versa. Stock returns are reciprocal from investors for their decisions that invest in certain companies. Return of Stock can be realized 
returns and expected returns. Return realization is a return that has occurred, which can be calculated using historical data. While the expected return is the return expected by investors in the future.

Components in stock returns can be capital gain (loss) and yield, capital gain (loss) is the increase or decrease in the price of a stock that can provide profits or losses for investors. While yield is a return component that reflects cash flow or income obtained periodically from a stock investment. Where:

According to Brigham and Houston (2006), to calculate stock returns used the following formula:

$R_{i, t} / R_{t} \quad=$ Return of Stock during the observation period

$P t$ or $P_{1} \quad$ = Price of Stock for the observation period

$P_{t-1}$ or $P_{0} \quad=$ Price of Stock Before the observation period

$$
\mathrm{R}_{\mathrm{t}}=\frac{P 1-P 0}{P 0}
$$

According to Jogiyanto (2008), to calculate the abnormal return a model is needed to estimate it because after an event occurs, the return that occurs is not a normal return, but the actual total return.

\section{Abnormal Return}

Abnormal Return is the difference between the actual return and the expected return that can occur before official information is published or leakage of information has occurred after official information has been published. According to Jogiyanto (2008), abnormal returns can be formulated as data :

Where:

$\mathrm{ARi}, \mathrm{t} \quad=$ Abnormal Return

$\mathrm{ARi}, \mathrm{t}=\mathrm{Ri}, \mathrm{t}-\mathrm{E}(\mathrm{Ri}, \mathrm{t})$

Ri,t = Actual Return

$\mathrm{E}[\mathrm{Ri}, \mathrm{t}]=$ Expected Return

Where as to get the expected return, according to Brown and Warner (1985) in Jogiyanto (2008) estimate the expected return with using 3 (three) estimation models, namely: mean adjusted model, market model and market adjusted model. In this case we used market adjusted model, Market adjusted model is a model that estimates the return of a company by using market index returns for a certain period. This model is used without the need to use the estimation period because the estimate is the same as the market index return.

\section{Trade Volume Activity}

To make investment decisions, investors will consider the risks and expected level of profits. So investors need information to do stock analysis. The existence of information spread on the capital market can change investor confidence in making investment decisions. Any information circulating will cause a market reaction. The market reaction can be seen from the activity of trade volume activity.

According to Tandelilin (2010), trade volume activity is a technical analysis decision in the transaction of shares based on past price data and trade volume activity. Trade volume activity is the sum of every transaction that occurs on the exchange at a certain time on certain shares.

Trade volume activity is also one of the factors that influence stock movements. According to Randa and Wiese (2012) in Azka (2017) To calculate the formula for Trade volume activity the following formula is used :

$$
\text { TVAit }=\frac{\text { Eshare trade at the certainly time }}{\sum \text { listed share }}
$$

After the trade volume activity is known then calculated the average trade volume activity in the observation period with the formula :

$$
\mathrm{XTVAt}=\frac{\sum T V A i}{n}
$$

Where:

XTVA $t=$ Average TVA during observation eriod

$\sum$ TVA $i=$ Total TVA during observation period

$n \quad=$ Total Sample

\section{Market Efficiency}

According to Fama (1970), the market is said to be efficient if the price formed in the market is a reflection or reaction of existing information. According to Tandelilin (2010), an efficient market is if the stock price is traded on the market has reflected all available information. According to Fama (1970) in Alteza (2007) Market efficiency in information can be grouped into three types, based on the type of information. 
1. Market efficiency is a weak form if the stock price has fully described the information that existed in the past. In this kind of market, the stock price follows a random walk so that the stock price that has already occurred cannot be used to predict the current stock price. Thus trading strategies are based on relationships.

2. Market Efficiency is a semi-strong form (semistrong form) if the stock price fully describes all the information that has been published..

3. Market efficiency is said to be a strong form if the stock price has described all available information both published and private.

\section{Signalling Theory}

According to Jogiyanto (2008), information generated as an announcement will signal investors in making investment decisions. If the announcement is positive it means the market will react at the time of the announcement. The investor will interpret and analyze the information as a signal of good news or bad news. The signaling theory used in this study is more directed at signals captured by investors regarding various relevant information that enters the capital market. The signal can be positive or negative. If positive, investors will be interested in investing.

\section{Anomaly of Market}

The phenomenon of deviation from the efficient capital market hypothesis is known as an anomaly, because it lasts for a long time and in a significant amount. Market anomalies are deviations from the efficient market concept whose causes are difficult to explain quickly. Anomalies in question are one form of a phenomenon that exists in the market, where the emergence of things that should not exist if it is considered that the efficient market really exists. According to Alteza (2007), market anomalies are classified into four, namely company anomalies (firm anomalies) such as firm size, seasonal anomalies (seasonaly anomalies, event or event anomalies (event anomalies), and accounting anomalies (accounting anomalies).

\section{Ramadhan Effect}

Ramadhan is an event that can affect the economy, including activities in the capital market. According to Akrami et al (2012) in Syarifatul Aimah (2015) Ramadhan Securities is one of the market anomalies, which are seasonal anomalies which indicate a difference in average returns in the month of Ramadhan compared to other months in one year. In the results of Bialowski's research, Etebari and Wisniewski (2011) on stock market anomalies during the Muslim holy month, specifically concluded that the evidence of the effects of Ramadhan was strong. In particular, during the holy month the average annual return yield was significantly higher (38.09\% vs. $4.32 \%$ ) than the average return for the rest of the year.

According to Al-Hajieh et al., Al-Khazali (2014), in Ariwar and Imam (2016) the effect of Ramadhan is proven to affect positive mood and investor trading behavior, which is reflected in stock returns which increased significantly during Ramadhan compared to non-days -Ramadhan. Ramadhan is one of the world famous religious traditions. An event which is celebrated every year by Muslims throughout the world, including Indonesia as the largest Muslim-majority country in the world. The phenomenon of increasing public consumption in the month of Ramadhan is said to be a phenomenon that causes a return in Ramadhan that is different from the month outside of Ramadhan.

\section{Data And Specification}

This type of research is the Event Study. Event Study is a technical research that allows researchers to assess the impact of a particular event on changes in stock prices. The Event Study is conducted to test the hypothesis. The hypothesis testing is done to test the difference in abnormal stock returns and trade volume activity (TVA) before and after the Ramadhan month in the period 2012-2017 (1433-1438H).

The time period for observations in this study is 2 months, namely at 19 days in the month of Sya'ban, and 19 days in Shawwal to see the events of the market reaction during the events of Ramadhan. The determination of the event window is expected to react to the market. The event window can be described as follows :

\section{Event Window}

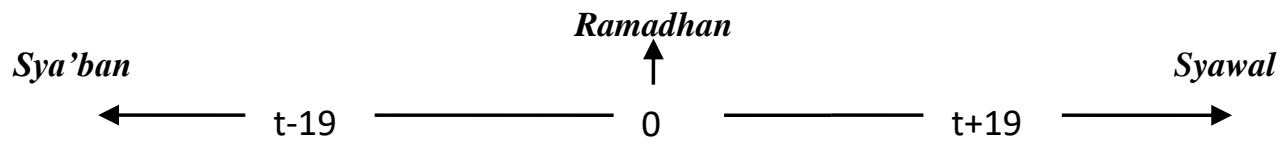

The type of data used in this study is to use secondary data. According to Sugiyono (2016), Secondary data is the data needed to support the results of research derived from literature, articles and various other sources related to research. Secondary data used in this study are data published in the period 2012-2017 and can be obtained from the website www.idx.co.id and https://finance.yahoo.com.

Ramadhan is an event that can affect the economy, including activities in the capital market. The Ramadhan period in this study is from 2012-2017 (1433H-1438H), that is: 
Table 1. The Ramadhan Period's Study

\begin{tabular}{ccc}
\hline No & Years & Ramadhan Periode \\
\hline 1. & 2012 (1433 Hijriah) & 19 July 2012 - 18 August 2012 \\
\hline 2. & 2013 (1434 Hijriah) & 8 July 2013 - 07 August 2013 \\
\hline 3. & 2014 (1435 Hijriah) & 29 June 2014 - 27 July 2014 \\
\hline 4. & 2015 (1436 Hijriah) & 20 June 2015 - 28 july 2015 \\
\hline 5. & 2016 (1437 Hijriah) & 06 June 2016 - 05 july 2016 \\
\hline 6. & 2017 (1438 Hijriah) & 27 May 2017 - 24 june 2017
\end{tabular}

Source: Data Processed, 2019

The population in this study are food and beverages companies that are listed or listed in the Indonesian Syariah Stock Index from 2012 to 2017, which are as many as 11 companies (quoted from www.sahamok.com). The sampling technique used in this study is non probability sampling, namely purposive sampling. According to Sugiyono (2016), purposive sampling is a sampling technique with data sources taken on certain considerations. Some of the considerations taken in taking this research sample include:

1. Food and beverages companies registered in the 2012-2017 Indonesian Sharia Stock Index (ISSI).

2. Food and beverages companies that are actively traded during the month of Ramadhan.

3. Food and beverages companies whose data is available in full for analysis need

Table 2. The Companies of Sampling

\begin{tabular}{cclc}
\hline No. & Code & \multicolumn{1}{c}{ Emiten Name } & Shariah Stocks \\
\hline 1 & AISA & Tiga Pilar Sejahtera Food Tbk & Yes \\
\hline 2 & ICBP & Indofood CBP Sukses Makmur Tbk & Yes \\
\hline 3 & INDF & Indofood Sukses Makmur Tbk & Yes \\
\hline 4 & MYOR & Mayora Indah Tbk & Yes \\
\hline 5 & ROTI & Nippon Indosari Corpindo Tbk & Yes \\
\hline 6 & STTP & Siantar Top Tbk & Yes \\
\hline 7 & ULTJ & Ultrajaya Milk Industry & Yes \\
\hline
\end{tabular}

Source: Data Processed, 2019

\section{The Result of Research}

\subsection{Normality Test}

To do a hypothesis test a normality test is needed. The normality test aims to test whether the data is normally distributed or not. To test whether the data is normally distributed or not normal, the researcher uses the Kolmogrov-Smirnov analysis as follows: 
Table 3. One-Sample Kolmogorov-Smirnov Test

\begin{tabular}{|c|c|c|c|c|c|}
\hline & & $\begin{array}{c}\text { AbnormalReturn } \\
\text { Syaban }\end{array}$ & $\begin{array}{c}\text { AbnormalReturn_ } \\
\text { Syawal } \\
\end{array}$ & TVA_Sya'ban & TVA_Syawal \\
\hline \multicolumn{2}{|l|}{$\mathrm{N}$} & 42 & 42 & 42 & 42 \\
\hline \multirow{2}{*}{$\begin{array}{l}\text { Normal } \\
\text { Parameters }{ }^{\mathrm{a}, \mathrm{b}} \\
\end{array}$} & Mean & .002098 & -.001155 & .001524 & .000810 \\
\hline & Std. Deviation & .0047282 & .0049751 & .0019660 & .0011096 \\
\hline \multirow{3}{*}{$\begin{array}{l}\text { Most Extreme } \\
\text { Differences }\end{array}$} & Absolute & .122 & .117 & & .337 \\
\hline & Positive & .122 & .085 & .319 & .337 \\
\hline & Negative & -.074 & -.117 & -.219 & -.233 \\
\hline \multicolumn{2}{|l|}{ Test Statistic } & .122 & .117 & .319 & .337 \\
\hline \multicolumn{2}{|c|}{ Asymp. Sig. (2-tailed) } & $.124^{\mathrm{c}}$ & $.166^{\mathrm{c}}$ & $.000^{\mathrm{c}}$ & $.000^{c}$ \\
\hline
\end{tabular}

Table 4.

Abnormal Return

Paired Samples Test

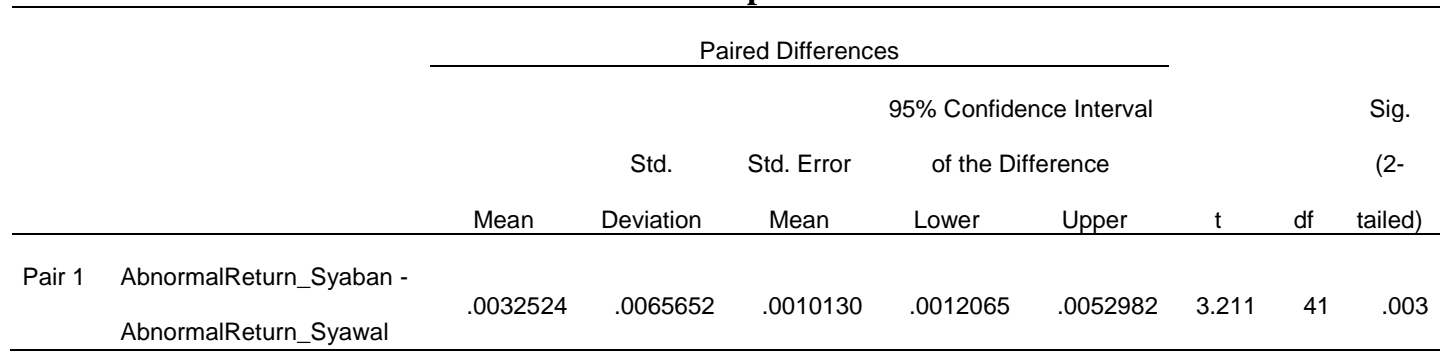

Source: Data Processed, 2019

\subsection{Hypotesist Test}

Based on previous normality tests using Kolmogrov Smirnov. Data previously obtained is normally distributed so parametric statistical tests can be carried out using paired sample t-test. The following results of the hypothesis I test using a paired sample t-test

Based on the results of the paired sample t-test from Table 4, it shows that t-count is greater than t-table $3.211>2.019$ and after Ramadhan, H1 can be accepted and significance $0.003<0.05$ means that hypothesis I is accepted means that there are significant differences from abnormal return before and after the events of Ramadhan in the period 2012-2017.

Table 5. Trade Volume Activity Ranks

\begin{tabular}{|c|c|c|c|}
\hline & $\mathrm{N}$ & Mean Rank & Sum of Ranks \\
\hline TVA_Syawal - TVA_Sya'banNegative Ranks & $15^{\mathrm{a}}$ & 10.20 & 153.00 \\
\hline Positive Ranks & $3^{\mathrm{b}}$ & 6.00 & 18.00 \\
\hline Ties & $24^{\mathrm{c}}$ & & \\
\hline Total & 42 & & \\
\hline
\end{tabular}

Source : Data Processed by IBM SPSS 23, 2019
a. TVA_Syawal $<$ TVA_Sya'ban
b. TVA Syawal $>$ TVA Sya'ban
c. TVA_Syawal $=$ TVA_Sya'ban

Based on the ranks Table 5 above shows that negative ranks are greater than positive rank (153.00> 18.00). This means trading activity volume before Ramadhan is higher than trading volume activity after Ramadhan. 
Table 6

Test Statistics ${ }^{\mathrm{a}}$

\begin{tabular}{ll}
\hline & TVA_Syawal \\
& TVA_Sya'ban \\
$Z$ & $-3.023^{\text {b }}$ \\
\hline Asymp. Sig. (2-tailed) & .003 \\
\hline
\end{tabular}

a. Wilcoxon Signed Ranks Test

b. Based on positive ranks.

Source : Data Processed, 2019

Based on the results of the Wilcoxon signed rank test from Table 6 shows that the significance of Asymp sig. 2-tailed $0.003<0.05)$ means that hypothesis II is accepted, meaning that there are significant differences from trade volume activity before and after the events of Ramadhan.

\section{Conclusion and Implication}

Based on the discussion that has been done in the previous chapter, this study aims to analyze the differences in abnormal return and trade volume activity before and after the events of the Ramadhan month in food and beverages companies that are listed on the Indonesian Syariah Stock Index for the period 2012$2017(1433-1438 \mathrm{H})$, in this study are as follows:

a. Based on parametric statistical tests using paired sample t-test there are significant differences from abnormal returns before and after the events of Ramadhan. The occurrence of abnormal returns is caused by investors who respond quickly to the events of Ramadhan. Investors pay attention to market changes by making analysis and calculations to expect abnormal returns. The capital market in Indonesia can be said to be an efficient information form because investors are able to interpret the information content of an event that occurs such as the effects of Ramadhan.

b. Based on the non-parametric statistical test using the Wilcoxon sign rank test obtained there are significant differences from trade volume activity before and after the events of the month of Ramadhan. The market information content of the ramadhan effect was responded to by the market because there was a significant difference in trade volume activity in the Sya'ban and Shawwal months. In the month period, Sya'ban trade volume activity values tend to be higher. This is because the investors respond to stocks that will strengthen during the month of Ramadhan, one of which is in the food and beverages sector. Whereas after the observation period, namely in the month of Shawwal the trade volume activity has decreased, this is due to the fact that investment operators tend to be careful in analyzing the information received in the last month.

\section{References}

Alteza M, 2007, Efek Hari Perda gangan Terhadap Return Saham: Suatu Telaah atas Anomali Pasar Efisien, Jurnal:Yogyakarta.

Bialkowski J, 2011, Stock Market Anomaly during the Muslim Holy Month. Jurnal : Economic and Finance.

Brigham, Eugene F dan Houston, 2006 Fundamental of Financial Management: Dasar-Dasar Manajemen Keuangan. Edisi 10. Jakarta: Salemba Empat-Jakarta

Fama EF, 2009, American Finance Association Efficient Capital Markets: A Review of Theory and Empirical Work.Jurnal: Vol 25 No.2.

Jogiyanto, 2008, Teori Portofolio dan Analisis Investasi Edisi Kelima, Yogyakarta: BPFE-Yogyakarta.

M.Azka Kesuma, 2017. Efek Ramadhan Terhadap Abnormal Return Dan Trading Volume Activity pada perusahaan yang masuk ke dalam Jakarta Islamic Index Di Bursa Efek Indonesia Periode 2011-2017. Skripsi.Universitas Lampung.

Sugiyono, D. R. (2016). Metode Penelitian Administrasi. Bandung, Alfabeta.

Syarifatul A, 2015, Reaksi Abnormal Return Dan Trading Volume Activity Terhadap Ramadhan Effect ( Studi Pada Perusahaan Food And Beverages Yang Terdaftar Di Bursa Efek Indonesia Periode 2013. 2014). Jurnal:Adm Bisnis Vol:27 No.1

Tandelilin E, 2010, Analisis Investasi dan Manajemen Portofolio Edisi Pertama, Yogyakarta: BPFEYogyakarta.

\section{Authors' Bibliography}

Titin Hartini was born in Palembang, Sumatera Selatan on September 22 $2^{\text {nd }}, 1975$. She graduated the bachelor degree from Economic Faculty, University of Sriwijaya in 1998, and master degree from Gadjah Mada University in 2003. Currently, Titin Hartini on progress to accomplish the doctoral program of Finance Management in Economic Faculty, University of Jambi. 